Citation: P. Canzoniere, S. Francesconi, S. Giovando, G. M. Balestra(2021) Antibacterial activity of tannins towards Pseudomonas syringae pv. tomato, and their potential as biostimulants on tomato plants. Phytopathologia Mediterranea 60(1): 23-36. doi: 10.36253/ phyto-11732

Accepted: October 10, 2020

Published: May 15, 2021

Copyright: (c) 2021 P. Canzoniere, S. Francesconi, S. Giovando, G. M. Balestra. This is an open access, peerreviewed article published by Firenze University Press (http://www.fupress. $\mathrm{com} / \mathrm{pm}$ ) and distributed under the terms of the Creative Commons Attribution License, which permits unrestricted use, distribution, and reproduction in any medium, provided the original author and source are credited.

Data Availability Statement: All relevant data are within the paper and its Supporting Information files.

Competing Interests: The Author(s) declare(s) no conflict of interest.

Editor: Roberto Buonaurio, University of Perugia, Italy.
Research Papers

\section{Antibacterial activity of tannins towards Pseudomonas syringae pv. tomato, and their potential as biostimulants on tomato plants}

\author{
Paolo CANZONiere ${ }^{1}$, Sara FRANCESCONI ${ }^{1}$, Samuele GIOVANDO ${ }^{2}$, \\ GioRgio M. BALESTRA ${ }^{1, *}$ \\ ${ }^{1}$ Dipartimento di Scienze Agrarie e Forestali (DAFNE), Università degli Studi della Tus- \\ cia, Via San Camillo de Lellis, 01100, Viterbo, Italy \\ ${ }^{2}$ Centro Ricerche per la Chimica Fine Srl, Via Torre, 7, 12080, San Michele di Mondovi \\ $(\mathrm{CN})$, Italy \\ ${ }^{*}$ Corresponding author. E-mail: balestra@unitus.it
}

\begin{abstract}
Summary. Pseudomonas syringae pv. tomato (Pst), the causal agent of bacterial speck of tomato, is a significant cause of economic losses in tomato crops. This disease is mainly controlled with preventive use of cupric salt formulations. Antibacterial activity of the tannins U1, U2, U3 and U4, applied alone at $1 \% \mathrm{w} / \mathrm{v}$ concentration or in combination with half $(0.045 \% \mathrm{w} / \mathrm{v})$ of standard of copper hydroxide treatments, was assayed for effects on Pst. In vitro, the four tannins completely inhibited Pst colony formation after $24 \mathrm{~h}$, but $\mathrm{U} 2$ (quebracho tannins) $+1 / 2 \mathrm{Cu}(\mathrm{OH})_{2}$ allowed Pst growth after $48 \mathrm{~h}$ of incubation, indicating that, since $\mathrm{U} 2$ is composed of high molecular condensed tannins it is likely that their structures have chelated the copper hydroxide much more then hydrolysable ones, thus inactivating copper hydroxide and tannins. In fact, this activity of the tannins was equivalent to that for $0.045 \% \mathrm{w} / \mathrm{v}$ of copper hydroxide. Effects of tannins on tomato plant growth were also assessed. On seedlings, long-term U1 treatments increased dry weight of shoots compared to copper hydroxide, but not to water treatment. The U4 treatment increased the NBI values compared to copper treatment but did not show significant differences compared to the water treatment. Inhibitory activity of tannin treatments reduced disease by $37-62 \%$, and $60 \%$ after copper treatment, while disease severity was reduced by $33-54 \%$ after treating plants with tannins and $36 \%$ after copper treatment. On mature plants treated once, the disease reduction was $27-39 \%$ after tannin treatments and $44 \%$ after copper treatment, while severity was reduced by $50-60 \%$ from tannin treatments, and $47 \%$ by copper. In seedlings and mature plants, these reductions were similar $(P>$ 0.05 ) for the tannins and copper treatments. This study indicates a novel crop protection strategy using natural products as alternatives to xenobiotic compounds.
\end{abstract}

Keywords. Bacterial speck, antibacterial activity, plant growth promotion, eco-friendly strategies.

\section{INTRODUCTION}

Pseudomonas syringae pv. tomato (Okabe) Alstatt (Pst) is the causal agent of bacterial speck on tomato plants (Solanum lycopersicum L.), and is capa- 
ble of causing considerable economic losses from tomato crops. The pathogen survives as an epiphyte on weeds and on symptomless tomato transplants, as well as in the soil and in host seeds (Devash et al., 1980; McCarter et al., 1983), utilizing molecules released from leaves and organic matter carried by the wind (Schneider and Grogan, 1976). Bacterial speck symptoms can affect various plant organs. On leaflets, where the pathogen penetrates into depressions between epidermal cells, substomatal chambers and around trichomes, speck symptoms appear as black spots, usually surrounded by yellow halos. Lesions on tomato fruit are small raised black spots, often surrounded by green halos (Varvaro et al., 1993). Fruit developed on defoliated plants are small, thus reducing the quality of fresh and processed tomatoes (Gruda, 2005; Pietrarelli et al., 2006).

Control of bacterial diseases is mainly based on appropriate agronomic practices, including use of healthy seeds, balanced fertilisation, crop rotation, and design of irrigation systems, to limit the spread of the pathogens (Quattrucci et al., 2013). As regards chemical control, Cupric salts are important pesticide components for management of phytopathogenic bacteria in conventional and organic agriculture (La Torre et al., 2018). Due to European restrictions on the use of copper, Pst control strategies based on low environmental impact and substitution of copper compounds are urgently required (Quattrucci and Balestra, 2009). This approach is already obtaining positive results for control of pathogens that cause parenchymatic and vascular diseases in tomatoes (Quattrucci and Balestra, 2009; Baka and Rashad, 2016; Kalleli et al., 2020). Nevertheless, Marrone (2019) stated, "there is still a relatively low percentage of naturally derived pesticides relative to the number of pharmaceuticals derived from natural sources". Effective pest management is a major challenge in modern agriculture, where control efficacy, cost affordability, environmental safety, toxicity towards non-target organisms, and sustainability of the production system are important factors (Vurro et al., 2019).

Tannins are polyphenolic secondary metabolites abundant in vascular plants, commonly occurring at $5-10 \%$ dry weight of plant biomass (Haslam et al., 1988; Lochab, 2014). They are the third most abundant components extracted from biomass, after cellulose, hemicelluloses and lignin (Arbenz and Avérous, 2016). Furthermore, they are mainly involved in plant protection through mechanisms of direct action on microbial pathogens, insects and herbivorous animals (Barbehenn and Constabel, 2011). The conventional extract process for tannins is based on plentiful water, which is partly recycled based mainly on solid/liquid extraction. Oth- er extraction techniques, including extractions based on supercritical fluid, pressurized water, microwaves, or ultrasound, are applied for laboratory studies (De Hoyos-Martínez et al., 2019). Due to the heterogeneous nature of tannins, a universal method can be used for their extraction (Bacelo et al., 2016).

Two of the most important classes of tannins are the hydrolysable and condensed varieties. Hydrolysable tannins are multiple esters of gallic acid with glucose and products of their oxidative reactions, and these have molecular weights from 500 to $3,000 \mathrm{Da}$. Condensed tannins (syn. proanthocyanidins) are derivatives of catechin and esters of gallic acid with quinic acid, and these compounds have molecular weights from 1,000 to 20,000 Da (Hümmer and Schreier, 2008; Quideau et al., 2011; Aroso et al., 2017). Hydrolysable tannins include gallotannins and ellagitannins. Upon hydrolysis by acids, bases or certain enzymes, gallotannins yield glucose and gallic acid, while ellagitannins produce the hydroxydiphenoyl residue; the latter undergoes lactonization to produce ellagic acid, which is not easily hydrolyzed because of the further C-C coupling of the polyphenolic residue with the polyol unit. So it should be mentioned that ellagitannins are not hydrolysable but are nevertheless for historical reasons classified as hydrolysable tannins. (Hernes and Hedges, 2004). Condensed tannins are polymers of flavonoids and their building block includes catechin and epicatechin. Condensed tannins can have different degrees of polymerization (between 3 and 11), depending on the linkage between the elementary units, which can be $\mathrm{C}-\mathrm{C}$ or occasionally C-O-C. Their condensation occurs through an oxidative reaction between the $\mathrm{C}_{4}$ carbon of the heterocycle and $\mathrm{C}_{6}$ or $\mathrm{C}_{8}$ carbons (Venter et al., 2012).

Many industrial tannins with agri-food applications are extracted from different plant species. In the present study tannins from three different sources were assayed: from sweet chestnut, tara pods or quebracho. Chemical characteristic of the tannins used have been reported in the Materials and Methods section. For agricultural uses of condensed tannins, their efficacy in plant protection has assessed against the gram-negative phytopathogenic bacterium Pseudomonas savastanoi pv. neri, where some extracts showed inhibitory activity on the Type Three Secretion System (TTSS) and in Quorum Sensing (QS). Grapeseed polyphenolic extracts consisted of several catechins and epicatechins, with molecular weights ranging from 290 to $1,170 \mathrm{Da}$, and of free gallic acid (0.004 $\mathrm{mg} \mathrm{g}^{-1}$ ), while the phytocompounds in green tea extracts were epigallocatechin gallate $\left(839 \mathrm{mg} \mathrm{g}^{-1}\right)$ and epicatechin gallate (32 $\left.\mathrm{mg} \mathrm{g}^{-1}\right)$ (Biancalani et al., 2016). 
Hydrolysable tannins are mainly extracted from sweet chestnut, and several studies have assessed how these compounds counteract plant pathogens. Tests on potato plants inoculated with Meloidogyne javanica (Treub) Chitwood showed reductions of nematode egg numbers in vitro and reproduction rates in vivo (Renčo et al., 2012). A crude methanol extract of Sapium baccatum (Roxb) has been shown to be highly active against Ralstonia solanacearum (Smith) with in vitro and in vivo tests ( $\mathrm{Vu}$ et al., 2017). The antibacterial effect of tannins on watermelon seeds has been demonstrated, with reduction of symptoms caused by Acidovorax citrulli from inoculated seeds and increased germination, following treatments with a product (AGRITAN ${ }^{\circ}$, Silvateam S.p.A.) containing plant polyphenol extracts based on tannins. The hypothesis that tannins could also induce host resistance has been advanced (Giovanardi et al., 2015). A raw sweet chestnut hydrolysable extract has found application as a biostimulant in transplanted tobacco crops, as a starter treatment boosting early root growth through phosphate uptake, making plants resistant to pathogens including nematodes, and thus allowing reduced usage of xenobiotic products (Bargiacchi et $a l, .2013,2017)$. In agriculture, hydrolysable tannins are also used as organic acidifying solutions and iron fertilizers. Iron fertilization occurs due to the metal chelation proprieties of tannins (Bargiacchi et al., 2004). Although studies have evaluated the biostimulant activities of tannins applied to plant roots and seeds, none have focused on the biostimulant activity of tannins nebulised on leaves.

The present study evaluated tannins antibacterial activity towards Pst, and potential biostimulant activity towards host plants. Three tannins from different plant sources were used to prepare four formulations (U1, U2, U3, and U4). Tannins were assessed for applications of these products onto tomato plant leaves at different stages of plant growth.

\section{MATERIALS AND METHODS}

\section{Tannin chemical characteristics}

\section{Tannin formulations}

Tannin components in the different formulations were: U1, sweet chestnut (Castanea sativa) hydrolysable tannins water extract; U2, sulfited quebracho (Schinopsis lorentzii) condensed tannins water extract; U3, a mixture (1:9) of tara (Casealpina spinosa) pods solvent extract of hydrolysable tannins and sweet chestnut hydrolysable tannins water extract; and U4, a mixture
(1:1) of sweet chestnut hydrolysable tannins water extract and sulfited quebracho condensed tannins water extract. Each product assayed was a liquid formulation, containing $40 \%$ tannins and $60 \%$ water, and was provided by Silvateam S.p.A. (San Michele Mondovì, Italy).

The chemical structures of the tannins assayed in this study were previously characterized by Pizzi et al. (2009), Giovando et al. (2013), Radebe et al. (2013). Turkey gall, and chestnut woods were analyzed and compared using matrix-assisted laser desorption/ionization time-of-flight (MALDI-TOF and Molino et al. (2018).

In vitro effects of tannins on Pseudomonas syringae $p v$. tomato

\section{Bacterium culture}

Pseudomonas syringae pv. tomato isolate CFBP-1323 from the French Bacterial Collection was used in this study. The isolate was stored at $-80^{\circ} \mathrm{C}$, and was grown according to King et al. (1954) at $25 \pm 1^{\circ} \mathrm{C}$ for $24 \mathrm{~h}$ for the preparation of inoculum. Bacterium suspensions were prepared in $0.01 \mathrm{M} \mathrm{MgSO}_{4}$, and adjusted to $1 \times 10^{6}$ $\mathrm{CFU} \mathrm{mL} \mathrm{mL}^{-1}$ at $\mathrm{OD}_{600}$.

Bacterium inhibition and growth on tannin-containing media

The minimum inhibitory concentrations (MICs) of the tannins were assayed by testing five concentrations of each, at $0.2,0.5,1,1.5$, or $2 \%(\mathrm{w} / \mathrm{v})$, following the protocol reported in Francesconi et al. (2020). The tannins were dissolved in sterile distilled water at these concentrations, and the solutions were then filtered using a sterile syringe filter $(0.2 \mu \mathrm{m}$ pore size). The filtered solutions were then pipetted into the microtiter plates, and bacterium suspension was added to each well to obtain final concentration of $1 \times 10^{4} \mathrm{CFU} \mathrm{mL}^{-1}$. The plates were then incubated at $27^{\circ} \mathrm{C}$ in the dark for $24 \mathrm{~h}$. Ten $\mu \mathrm{L}$ of each bacterium/tannin suspension were transferred into a new microtiter plate containing Nutrient Broth (NB), and incubated at $27^{\circ} \mathrm{C}$ in the dark for $48 \mathrm{~h}$. Absorbance from the resulting bacteria was measured at $\mathrm{OD}_{600}$, using a DR-200B Microplate reader (Diatek Instruments). Mock (untreated bacterium suspension cultured on NB) and blank (NB only) controls were also included.

The tannin formulations were incorporated into $\mathrm{KB}$ medium at $1 \%(\mathrm{w} / \mathrm{v})$. Copper hydroxide (standard) was used at $0.09 \%(\mathrm{w} / \mathrm{v})$, on the basis of average concentrations of cupric salts in many commercial formulations. Suspensions of tannins (at 10\% w/v) and copper hydrox- 
ide (at $0.9 \% \mathrm{w} / \mathrm{v}$ ) were each prepared in $100 \mathrm{~mL}$ of sterile deionised water. To obtain the final concentrations, 1 $\mathrm{mL}$ of each suspension was sterilised with $0.22 \mu \mathrm{m}$ pore size filters and added to $100 \mathrm{~mL}$ of the medium. The plates were inoculated with $100 \mu \mathrm{L}$ of Pst suspension $\left(10^{4}\right.$ $\mathrm{CFU} \mathrm{mL} \mathrm{m}^{-1}$ ) and incubated at $27^{\circ} \mathrm{C}$ for $48 \mathrm{~h}$. Three independent replicates were performed with three plates for each experimental group, and the CFU were determined after 24 and $48 \mathrm{~h}$.

\section{In vivo effects of tannin treatments}

Bacterium inoculations

Three hours before bacterium inoculation, the relative humidity where test plants were growing (see below) was increased to $95 \%$ to favour the opening of the leaf stomata. Inoculation were carried out by spraying each plant with $30 \mathrm{~mL}$ of bacterium suspension containing 1 $\times 10^{6} \mathrm{CFU} \mathrm{mL} \mathrm{m}^{-1}$, which was obtained by serial 1:10 dilutions (Katagiri et al., 2002).

Host plant material, growth conditions and experimental design

In the autumn of 2018, experiments were conducted in a glass greenhouse at the Tuscia University experimental farm (Viterbo, central Italy, $42^{\circ} 25^{\prime} \mathrm{N}, 12^{\circ} 08^{\prime} \mathrm{E}$ ). Tomato seedlings (Solanum lycopersicum L. cv. San Mar- zano; susceptible to Pst) were acquired from an organic nursery. The experimental design was a randomized complete-block design consisting of three independent experiments, each containing ten plants for each experimental group. The plants were kept in controlled conditions at $28 \pm 2{ }^{\circ} \mathrm{C}$ and 70 to $80 \%$ relative humidity. Seedlings at the cotyledon stage were transplanted into pots (15 cm diam.) containing a sterilised soil/sand/peat mix (2:1:1 volume), and were watered daily using drip irrigation. A mineral solution (N, P, K, 20:20:20 plus B, Cu, Fe, Mn, Mo, Zn, 1:5:30:10:10:10), at $2 \mathrm{~g} \mathrm{~L}$ was administered to the pots once each week, to maintain optimum nutritional conditions.

The seedling experiments commenced $15 \mathrm{~d}$ before inoculation, in which the tannin treatments were applied three times at 5, 10 and $15 \mathrm{~d}$. The mature plants were treated $1 \mathrm{~d}$ before inoculation with tannin formulations. Each experiment spanned $21 \mathrm{~d}$ from inoculation to final assessments.

To determine if there were phytotoxic effects of the tannin formulations used, the tannins were infiltrated into the mesophylls of tobacco leaves. No unspecific phytotoxicity was observed (data not shown). Tomato plants were also visually evaluated for phytotoxicity during each rating period.

The tannin treatments were applied to the seedlings and the mature plants with a $\mathrm{CO}_{2}$-pressurised handheld sprayer equipped with a large orifice nozzle (TeeJet 8004 ), operating at $2.8 \mathrm{~g} \mathrm{~cm}^{-1}$, to produce large spray droplets to runoff. The treatments applied were: $1 \%$ tan-

Table 1. Descriptions of treatments used in this study. tannins = hydrolysable and condensed tannins (U1 to U4).

\begin{tabular}{|c|c|c|c|}
\hline Treatment designation & Plant sources & $\begin{array}{l}\text { Extraction } \\
\text { mode }\end{array}$ & Description \\
\hline Ts (U1) & Sweet chestnut & Water & Tannin formulations provided by Silvateam used at $1 \%(\mathrm{w} / \mathrm{v})$. \\
\hline Ts (U2) & Quebracho & Water & \\
\hline \multirow[t]{2}{*}{ Ts (U3) } & Sweet chestnut + Tara pods $(9: 1)$ & Water & \\
\hline & & Solvent & \\
\hline Ts (U4) & Sweet chestnut + quebracho $(1: 1)$ & Water & \\
\hline Ts $(\mathrm{U} 1)+1 / 2 \mathrm{Cu}(\mathrm{OH})_{2}$ & & & $\begin{array}{l}\text { Tannin formulations at } 1 \%(\mathrm{w} / \mathrm{v}) \text { mixed with } 0.045 \%(\mathrm{w} / \mathrm{v}) \text {, } \\
\text { halved dose of the standard of copper hydroxide. }\end{array}$ \\
\hline \multicolumn{4}{|l|}{$\mathrm{Ts}(\mathrm{U} 2)+1 / 2 \mathrm{Cu}(\mathrm{OH})_{2}$} \\
\hline \multicolumn{4}{|l|}{$\mathrm{Ts}(\mathrm{U} 3)+1 / 2 \mathrm{Cu}(\mathrm{OH})_{2}$} \\
\hline \multicolumn{4}{|l|}{ Ts $(\mathrm{U} 4)+1 / 2 \mathrm{Cu}(\mathrm{OH})_{2}$} \\
\hline Pst (negative control) & & & Inoculated and untreated plants. \\
\hline $\mathrm{Cu}(\mathrm{OH})_{2}$ (standard $)$ & & & $\begin{array}{l}0.09 \%(\mathrm{w} / \mathrm{v}) \text { concentration (average concentration of cupric } \\
\text { salts in commercial formulations). }\end{array}$ \\
\hline $1 / 2 \mathrm{Cu}(\mathrm{OH})_{2}$ & & & $\begin{array}{l}0.045 \%(\mathrm{w} / \mathrm{v}) \text { concentration (halved dose of the standard of } \\
\text { copper hydroxide) }\end{array}$ \\
\hline TPE & & & Biostimulant commercial formulate at $0.2 \%(\mathrm{w} / \mathrm{v})$. \\
\hline $\mathrm{H}_{2} \mathrm{O}$ (blank control) & & & Water treatments used as no-biostimulant control treatment. \\
\hline
\end{tabular}


nins only; $1 \%$ tannins mixed with half of the standard dose $(0.045 \%)$ of copper hydroxide; full standard dose $(0.09 \%)$ of copper hydroxide; negative control (inoculated plants with no chemical treatments); or tropical plants extract (TPE) based, for biostimulant activity at $0.2 \%(\mathrm{w} / \mathrm{v})$ (Auxym ${ }^{\oplus}$, Italpollina S.p.A.); or blank control (water-treated plants). All combinations of these treatments are listed in Table 1.

Effects of treatments on epiphytic survival of Pseudomonas syringae pv. tomato

The in vivo antibacterial activity of tannins was evaluated by assessing epiphytic survival of Pst at 1, 7, 14, and 21 days post inoculation (dpi). For each experimental group, three independent replicates, each comprising nine plants, were evaluated. From each plant, one young leaflet from the latest treated apical meristem and one mature leaflet were sampled. The leaflets were transferred into a sterile plastic bag and washed with $10 \mathrm{~mL}$ of sterile distilled water at $180 \mathrm{rpm}$ for $10 \mathrm{sec}$, using a Stomacher 400 Circulator. The washing water $(100 \mu \mathrm{L})$ was then plated on the $\mathrm{KB}$ medium and incubated at $27^{\circ} \mathrm{C}$ for $24 \mathrm{~h}$ (Balestra and Varvaro, 1998). The numbers of CFUs were counted and were related to the surface areas of the sampled leaves, using APS Asses software. This procedure was used for each experimental group.

Effects of tannins on disease incidence, severity and disease reduction

Disease severity (\% DS) was assessed at 7, 14 and $21 \mathrm{dpi}$, and was scored using a $0-4$ scale where, $0=$ no symptoms; $1=$ one leaf with at least one necrosis; $2=$ two or three leaves with at least one necrosis; $3=$ four or five leaves with at least one necrosis; and $4=$ more than five leaves with at least one necrosis. Severity was calculated by the following equation:

$D S(\%)=\frac{\Sigma \mathrm{dn}}{D N} \times 100$

where, $d=$ severity score; $\mathrm{n}=$ number of diseased plants with the same severity score; $\mathrm{N}=$ total number of the examined plants, and $\mathrm{D}=$ the greatest severity score $(\mathrm{He}$ et al., 1983; Mekam et al., 2019). Proportional disease reduction (\% DR) was calculated using the following formula:

$D R(\%)=\frac{S-s}{S} \times 100$ where, $S=$ disease severity on tomato inoculated with Pst, and $s=$ disease severity on tomato treated with different formulations then inoculated with Pst.

Disease incidence (DI) was also calculated as a percentage of the symptomatic plants per experimental group (Steel et al., 1997).

DS, DR and DI were calculated from three independent experiments, each one consisting of ten plants.

Biostimulation of seedlings

Since the seedlings were treated three times, the biostimulant activity of tannins was assessed by measuring the average leaf surface area, nitrogen balance index (NBI) relating to the ratio of chlorophyll and the flavonoids, and the biomass development expressed as the ratio of shoot to root dry weights. The TPE-based biostimulant was used as positive control (Caruso et al., 2019), water-treated plants were considered as mock control, and copper-treated plants were the negative control. For each experimental group, three independent replicates were evaluated, each comprising nine plants. For each independent experiment, the plants were divided into three groups of three plants. For each group, six leaflets were harvested as follows: three young leaflets from the latest apical treated meristem and three mature leaflets. The measurements were obtained using APS Asses software, relating the total area of the leaflets and the number of leaflets sampled. For the evaluation of NBI, the measurements were performed $21 \mathrm{~d}$ after the treatments with tannins were applied. Data were collected between the midrib and margin of each leaf, and the NBI meter was shielded from direct sunlight. The measurements were obtained randomly from three independent experiments, each consisting of ten plants for each experimental group. Plant root and shoot dry biomass was determined by weighing the plant tissues before and after drying in a forced air oven at $80^{\circ} \mathrm{C}$ for $72 \mathrm{~h}$ (Colla et al., 2015). Three independent experiments were performed and for each experiment three plants were randomly sampled.

\section{Statistical analyses}

All the data were subjected to variance analyses (ANOVA) using DSAASTAT software. Two levels of significance $(P<0.05, P<0.01)$ were considered to assess the significance of the $F$ values. When significant $F$ values were calculated, pairwise analyses were carried out using the Tukey Honestly Significant Difference test (Tukey's test) at 0.95 or 0.99 confidence levels. 


\section{RESULTS}

In vitro effects of tannins on Pseudomonas syringae $p v$. tomato

MIC values of chestnut, tara and quebracho extracts, and their antibacterial activities in media

All the tannin formulations reduced Pst growth, and were bactericidal to the bacterium. At the concentration used, $\mathrm{pH}$ was in the range of within 6 to 7 , so $\mathrm{pH}$ did not influence the antibacterial activity. Tannins U1, U3 and U4 were the most effective forwards Pst, giving MIC values of $0.5 \%$, while the MIC for U2 was $1 \%$. Following these results, the concentration of $1 \%$ for tannins was used for further investigations. Table 2 shows the in vitro results after incorporating the tannins into $\mathrm{KB}$ medium at $1 \%$. After $24 \mathrm{~h}$ incubation, no Pst colonies were visible under the stereomicroscope on the media containing the tannin formulations, either where the four tannins were used alone or in mixture. This indicated that their antimicrobial activity at $24 \mathrm{~h}$ was comparable to that of a field dose of copper hydroxide. On KB plates containing the halved dose of copper hydroxide, 8.17E + $02 \mathrm{CFU} \mathrm{mL} \mathrm{m}^{-1}$ were counted. After $48 \mathrm{~h}$ incubation, three of the tannin formulations (U1, U3 and U4) used alone or mixed gave complete Pst inhibition. The exception

Table 2. Mean numbers $(n=10) \pm$ mean of the standard errors (SEM) of three independent replicates for each experimental group of colony forming units ( $\mathrm{CFU} \mathrm{mL} \mathrm{m}^{-1}$ ) of Pseudomonas syringae pv. tomato from different treatments containing tannin formulations, either alone or in mixtures with half $(0.045 \% \mathrm{w} / \mathrm{v})$ of standard of copper hydroxide, at 24 or $48 \mathrm{~h}$ after inoculation in $\mathrm{KB}$ plates containing the substances listed in Table 1.

\begin{tabular}{lcc}
\hline & \multicolumn{2}{c}{$\log \mathrm{CFU} \mathrm{mL}^{-1}$} \\
\cline { 2 - 3 } Treatment & $24 \mathrm{~h}$ & $48 \mathrm{~h}$ \\
\hline Ts $(\mathrm{U} 1)$ & TID & TID \\
Ts $(\mathrm{U} 2)$ & TID & TID \\
Ts $(\mathrm{U} 3)$ & TID & TID \\
Ts $(\mathrm{U} 4)$ & TID & TID \\
Ts $(\mathrm{U} 1)+1 / 2 \mathrm{Cu}(\mathrm{OH})_{2}$ & TID & TID \\
Ts $(\mathrm{U} 2)+1 / 2 \mathrm{Cu}(\mathrm{OH})_{2}$ & TID & $1.06 \mathrm{E}+03 \mathrm{~b}$ \\
Ts $(\mathrm{U} 3)+1 / 2 \mathrm{Cu}(\mathrm{OH})_{2}$ & TID & TID \\
Ts $(\mathrm{U} 4)+1 / 2 \mathrm{Cu}(\mathrm{OH})_{2}$ & TID & TID \\
Pst $($ negative control $)$ & $6.01 \mathrm{E}+03 \mathrm{a}$ & $6.01 \mathrm{E}+03 \mathrm{a}$ \\
$\mathrm{Cu}(\mathrm{OH})_{2}($ standard $)$ & TID & TID \\
$1 / 2 \mathrm{Cu}(\mathrm{OH})_{2}$ & $8.17 \mathrm{E}+02 \mathrm{~b}$ & $8.17 \mathrm{E}+02 \mathrm{~b}$ \\
$(\mathrm{SEM})$ & $2.34 \mathrm{E}+01$ & $3.04 \mathrm{E}+01$ \\
\hline
\end{tabular}

TID $=$ total inhibition determined. Different letters within the same column indicate significant differences $(P<0.01)$ according to the Tukey HSD test. was $\mathrm{U} 2+1 / 2 \mathrm{Cu}(\mathrm{OH})_{2}\left(1.06 \mathrm{E}+03 \mathrm{CFU} \mathrm{mL}^{-1}\right)$, which gave antimicrobial activity comparable to the halved dose of copper hydroxide $\left(8.17 \mathrm{E}+02 \mathrm{CFU} \mathrm{mL}^{-1}\right)$. Both these experimental groups significantly reduced Pst growth compared to the negative control $\left(6.01 \mathrm{E}+03 \mathrm{CFU} \mathrm{mL} \mathrm{m}^{-1}\right)$.

\section{In vivo effects of tannin treatments}

\section{Epiphytic survival of Pseudomonas syringae pv. tomato}

All of the tannin treatments were antibacterial, with activity at 1 dpi similar to that from copper hydroxide (Table 3). The tannins U4 applied alone $(8.58 \mathrm{E}+03$

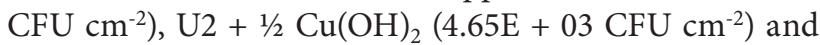

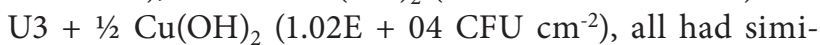
lar antibacterial activity. At $7 \mathrm{dpi}$, all the tannin treatments, with the exception of U2 $\left(2.86 \mathrm{E}+04 \mathrm{CFU} \mathrm{cm} \mathrm{cm}^{-2}\right)$ markedly reduced epiphytic survival of Pst compared to the negative control (Pst) $\left(4.05 \mathrm{E}+05 \mathrm{CFU} \mathrm{\textrm {cm } ^ { - 2 }}\right)$ and their antibacterial activity was similar to that of copper

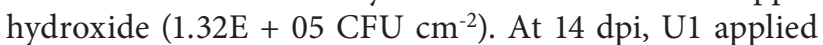
alone $\left(8.22 \mathrm{E}+03 \mathrm{CFU} \mathrm{cm}{ }^{-2}\right), \mathrm{U} 3+1 / 2 \mathrm{Cu}(\mathrm{OH})_{2}(2.04 \mathrm{E}$ $\left.+04 \mathrm{CFU} \mathrm{cm}{ }^{-2}\right)$ and $\mathrm{U} 3+1 / 2 \mathrm{Cu}(\mathrm{OH})_{2}(1.10 \mathrm{E}+04 \mathrm{CFU}$ $\mathrm{cm}^{-2}$ ), all reduced epiphytic survival of Pst compared to that in the negative control plants $(8.41 \mathrm{E}+04 \mathrm{CFU}$ $\mathrm{cm}^{-2}$ ), and showed antibacterial effects similar to that

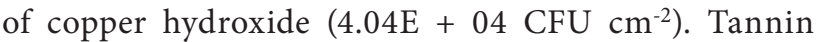
$\mathrm{U} 2\left(1.31 \mathrm{E}+05 \mathrm{CFU} \mathrm{\textrm {cm } ^ { - 2 }}\right)$ was not effective in reducing Pst epiphytic survival. At $21 \mathrm{dpi}$, all the tannins, either alone or in mixtures, reduced Pst growth on tomato leaves compared to the negative control plants (Pst). Furthermore, U1 $\left(6.16 \mathrm{E}+03 \mathrm{CFU} \mathrm{cm}{ }^{-2}\right), \mathrm{U} 2(5.06 \mathrm{E}+03$ $\left.\mathrm{CFU} \mathrm{cm}{ }^{-2}\right), \mathrm{U} 4\left(2.33 \mathrm{E}+03 \mathrm{CFU} \mathrm{cm}{ }^{-2}\right), \mathrm{U} 1+1 / 2 \mathrm{Cu}(\mathrm{OH})_{2}$ $\left(8.39 \mathrm{E}+03 \mathrm{CFU} \mathrm{cm}{ }^{-2}\right)$ and $\mathrm{U} 3+1 / 2 \mathrm{Cu}(\mathrm{OH})_{2}(8.31 \mathrm{E}+$ $02 \mathrm{CFU} \mathrm{cm} \mathrm{cm}^{-2}$ ), all reduced the epiphytic survival of Pst much more than the standard copper hydroxide treatment $\left(4.72 \mathrm{E}+04 \mathrm{CFU} \mathrm{cm}^{-2}\right)$, while U3 used alone showed intermediate values $\left(8.31 \mathrm{E}+02 \mathrm{CFU} \mathrm{\textrm {cm } ^ { - 2 }}\right)$.

On mature tomato plants (Table 3 ) at $1 \mathrm{dpi}$, all the tannin treatments (except U2 and U3 used alone) decreased epiphytic Pst populations, and gave populations similar to that from copper hydroxide. Tannin U1 and all the mixtures with tannins and copper reduced Pst populations similarly to copper hydroxide, and more than U2 and U3 used alone. At $7 \mathrm{dpi}$, no Pst colonies were recorded after copper hydroxide treatment, and this antibacterial effect was greater than from the tan-

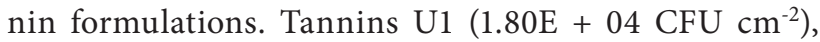
$\mathrm{U} 3\left(2.58 \mathrm{E}+04 \mathrm{CFU} \mathrm{cm} \mathrm{cm}^{-2}\right), \mathrm{U} 1+1 / 2 \mathrm{Cu}(\mathrm{OH})_{2}(4.06 \mathrm{E}+03$ $\left.\mathrm{CFU} \mathrm{cm}{ }^{-2}\right), \mathrm{U} 3+1 / 2 \mathrm{Cu}(\mathrm{OH})_{2}\left(1.18 \mathrm{E}+04 \mathrm{CFU} \mathrm{cm}{ }^{-2}\right)$ and $\mathrm{U} 4+1 / 2 \mathrm{Cu}(\mathrm{OH})_{2}\left(1.23 \mathrm{E}+04 \mathrm{CFU} \mathrm{cm}{ }^{-2}\right)$ were statistically similar among them. At $14 \mathrm{dpi}$, all the tannin treat- 
Table 3. Mean numbers $(n=10) \pm$ mean of the standard errors $(S E M)$ of three independent replicates for each experimental group of colony forming units (Log CFU cm${ }^{-2}$ ) of Pseudomonas syringae pv. tomato (Pst) from different treatments containing tannins, either alone or in mixtures with half $(0.045 \% \mathrm{w} / \mathrm{v})$ of standard of copper hydroxide, at $1,7,14$ and $21 \mathrm{~d}$ post inoculation (dpi) in tomato plants.

\begin{tabular}{|c|c|c|c|c|}
\hline \multirow{2}{*}{ Treatment } & \multicolumn{4}{|c|}{ Epiphytic survival (Log CFU $\mathrm{cm}^{-2}$ ) } \\
\hline & $1 \mathrm{dpi}$ & $7 \mathrm{dpi}$ & $14 \mathrm{dpi}$ & $21 \mathrm{dpi}$ \\
\hline \multicolumn{5}{|l|}{ Seedlings } \\
\hline Ts (U1) & $2.7 \mathrm{E}+04 \mathrm{bc}$ & $5.23 \mathrm{E}+04 \mathrm{c}$ & $8.22 \mathrm{E}+03 \mathrm{c}$ & $6.16 \mathrm{E}+03 \mathrm{de}$ \\
\hline Ts (U2) & $2.86 \mathrm{E}+04 \mathrm{bc}$ & $6.25 \mathrm{E}+05 \mathrm{a}$ & $1.31 \mathrm{E}+05 \mathrm{a}$ & $5.06 \mathrm{E}+03 \mathrm{de}$ \\
\hline Ts (U3) & $4.95 \mathrm{E}+04 \mathrm{bc}$ & $2.12 \mathrm{E}+04 \mathrm{c}$ & $2.04 \mathrm{E}+04 \mathrm{c}$ & $2.65 \mathrm{E}+04 \mathrm{~cd}$ \\
\hline Ts (U4) & $8.58 \mathrm{E}+03 \mathrm{c}$ & $1.60 \mathrm{E}+05 \mathrm{c}$ & $2.81 \mathrm{E}+04 \mathrm{bc}$ & $2.33 \mathrm{E}+03 \mathrm{e}$ \\
\hline Ts $(\mathrm{U} 1)+1 / 2 \mathrm{Cu}(\mathrm{OH})_{2}$ & $9.80 \mathrm{E}+04 \mathrm{~b}$ & $9.30 \mathrm{E}+04 \mathrm{c}$ & $2.96 \mathrm{E}+04 \mathrm{bc}$ & $8.39 \mathrm{E}+03 \mathrm{de}$ \\
\hline Ts $(\mathrm{U} 2)+1 / 2 \mathrm{Cu}(\mathrm{OH})_{2}$ & $4.65 \mathrm{E}+03 \mathrm{c}$ & $2.44 \mathrm{E}+04 \mathrm{c}$ & $5.26 \mathrm{E}+04 \mathrm{bc}$ & $4.96 \mathrm{E}+04 \mathrm{~b}$ \\
\hline Ts $(\mathrm{U} 3)+1 / 2 \mathrm{Cu}(\mathrm{OH})_{2}$ & $1.02 \mathrm{E}+04 \mathrm{c}$ & $6.76 \mathrm{E}+04 \mathrm{c}$ & $1.10 \mathrm{E}+04 \mathrm{c}$ & $8.31 \mathrm{E}+02 \mathrm{e}$ \\
\hline $\mathrm{Ts}(\mathrm{U} 4)+1 / 2 \mathrm{Cu}(\mathrm{OH})_{2}$ & $4.43 \mathrm{E}+04 \mathrm{bc}$ & $5.49 \mathrm{E}+04 \mathrm{c}$ & $4.42 \mathrm{E}+04 \mathrm{bc}$ & $3.69 \mathrm{E}+04 \mathrm{bc}$ \\
\hline Pst (negative control) & $1.79 \mathrm{E}+05 \mathrm{a}$ & $4.05 \mathrm{E}+05 \mathrm{~b}$ & $8.41 \mathrm{E}+04 \mathrm{ab}$ & $8.95 \mathrm{E}+04 \mathrm{a}$ \\
\hline $\mathrm{Cu}(\mathrm{OH})_{2}$ (standard) & $3.85 \mathrm{E}+04 \mathrm{bc}$ & $1.32 \mathrm{E}+05 \mathrm{c}$ & $4.04 \mathrm{E}+04 \mathrm{bc}$ & $4.72 \mathrm{E}+04 \mathrm{bc}$ \\
\hline (S.E.M.) & $1.50 \mathrm{E}+04$ & $3.56 \mathrm{E}+02$ & $1.19 \mathrm{E}+02$ & $4.48 \mathrm{E}+01$ \\
\hline$P$ value & $P<0.01$ & $P<0.01$ & $P<0.01$ & $P<0.01$ \\
\hline \multicolumn{5}{|l|}{ Mature plants } \\
\hline Ts (U1) & $2.50 \mathrm{E}+04 \mathrm{c}$ & $1.80 \mathrm{E}+04 \mathrm{c}$ & $1.74 \mathrm{E}+04 \mathrm{ab}$ & $1.93 \mathrm{E}+04 \mathrm{~b}$ \\
\hline Ts (U2) & $9.50 \mathrm{E}+04 \mathrm{~b}$ & $1.02 \mathrm{E}+05 \mathrm{ab}$ & $7.63 \mathrm{E}+03 \mathrm{bc}$ & $8.32 \mathrm{E}+02 \mathrm{~b}$ \\
\hline Ts (U3) & $9.07 \mathrm{E}+04 \mathrm{~b}$ & $2.58 \mathrm{E}+04 \mathrm{c}$ & $1.30 \mathrm{E}+03 \mathrm{c}$ & $3.61 \mathrm{E}+04 \mathrm{~b}$ \\
\hline Ts (U4) & $4.87 \mathrm{E}+04 \mathrm{bc}$ & $5.14 \mathrm{E}+04 \mathrm{bc}$ & $8.11 \mathrm{E}+03 \mathrm{bc}$ & $3.66 \mathrm{E}+02 \mathrm{~b}$ \\
\hline Ts $(\mathrm{U} 1)+1 / 2 \mathrm{Cu}(\mathrm{OH})_{2}$ & $1.38 \mathrm{E}+04 \mathrm{c}$ & $4.06 \mathrm{E}+03 \mathrm{c}$ & $755 \mathrm{E}+02 \mathrm{c}$ & $5.84 \mathrm{E}+04 \mathrm{~b}$ \\
\hline Ts $(\mathrm{U} 2)+1 / 2 \mathrm{Cu}(\mathrm{OH})_{2}$ & $1.73 \mathrm{E}+03 \mathrm{c}$ & $4.41 \mathrm{E}+04 \mathrm{bc}$ & $5.14 \mathrm{E}+02 \mathrm{c}$ & $1.75 \mathrm{E}+04 \mathrm{~b}$ \\
\hline Ts $(\mathrm{U} 3)+1 / 2 \mathrm{Cu}(\mathrm{OH})_{2}$ & $2.55 \mathrm{E}+04 \mathrm{c}$ & $1.18 \mathrm{E}+04 \mathrm{c}$ & $6.78 \mathrm{E}+02 \mathrm{c}$ & $1.70 \mathrm{E}+03 \mathrm{~b}$ \\
\hline $\mathrm{Ts}(\mathrm{U} 4)+1 / 2 \mathrm{Cu}(\mathrm{OH})_{2}$ & $1.47 \mathrm{E}+04 \mathrm{c}$ & $1.23 \mathrm{E}+04 \mathrm{c}$ & $5.45 \mathrm{E}+02 \mathrm{c}$ & $5.33 \mathrm{E}+03 \mathrm{~b}$ \\
\hline Pst (negative control) & $2.03 \mathrm{E}+05 \mathrm{a}$ & $1.26 \mathrm{E}+05 \mathrm{a}$ & $2.36 \mathrm{E}+04 \mathrm{a}$ & $1.45 \mathrm{E}+05 \mathrm{a}$ \\
\hline $\mathrm{Cu}(\mathrm{OH})_{2}$ (standard) & $8.73 \mathrm{E}+01 \mathrm{c}$ & $0.00 \mathrm{E}+00 \mathrm{~d}$ & $5.37 \mathrm{E}+02 \mathrm{c}$ & $1.17 \mathrm{E}+02 \mathrm{~b}$ \\
\hline (S.E.M.) & $1.13 \mathrm{E}+04$ & $1.16 \mathrm{E}+04$ & $1.95 \mathrm{E}+02$ & $1.26 \mathrm{E}+03$ \\
\hline$P$ value & $P<0.01$ & $P<0.01$ & $P<0.01$ & $P<0.01$ \\
\hline
\end{tabular}

Seedlings were treated 5, 10 and $15 \mathrm{~d}$ before inoculation, and mature plants were treated once at $24 \mathrm{~h}$ before inoculation. Treatments were with substances listed in Table 1 . The mean values in each column followed by different letters are significantly different $(P<0.01)$ according to the Tukey HSD test.

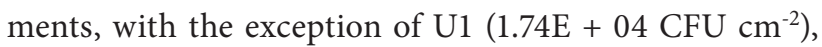
promptly contained Pst multiplication compared to that in the negative control plants (Pst) and showed antibacterial effects similar to that from copper hydroxide. Tannins U2 and U4 applied alone showed intermediate values and were similar among them. At $21 \mathrm{dpi}$, all the tannin treatments pointed out an antibacterial activity statistically similar to that in the positive control $(1.17 \mathrm{E}$

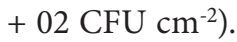

Disease severity and reduction

Table 4 presents data of the progress of bacterial speck as mean proportions (\%) of disease severity (DS) and disease reduction (DR). On seedlings, at $7 \mathrm{dpi}$, the tannins U1 (mean DS = 16.7\%), U2 (20.8\%), U4 (15.8\%), $\mathrm{U} 1+1 / 2 \mathrm{Cu}(\mathrm{OH})_{2}(24.2 \%)$ and $\mathrm{U} 3+1 / 2 \mathrm{Cu}(\mathrm{OH})_{2}(12.5 \%)$, all reduced the DS compared to that in the negative control (53.3\%). At 14 and $21 \mathrm{dpi}$ all the tannin treatments reduced mean DS values $(25-40 \%$ at $14 \mathrm{dpi}$ and $32-50 \%$ at $21 \mathrm{dpi}$ ) compared to the negative controls (75\% at 14 dpi and $87 \%$ at $21 \mathrm{dpi}$ ). The tannin treatments generally reduced the mean DR values, similarly to that from copper hydroxide. The exceptions were the $\mathrm{U} 4+1 / 2 \mathrm{Cu}(\mathrm{OH})_{2}$ and $\mathrm{U} 2+1 / 2 \mathrm{Cu}(\mathrm{OH})_{2}$ treatments, which gave mean DRs of $47.4 \%$ at $7 \mathrm{dpi}$ and $37.3 \%$ at $21 \mathrm{dpi}$, when the DR values were significantly less than from copper hydroxide (77.9\% at $7 \mathrm{dpi}$ and $59.0 \%$ at $21 \mathrm{dpi}$.

On mature plants (Table 4), at $7 \mathrm{dpi}$, all the tannin treatments gave similar mean DS values (20 to $36 \%$ ), 
Table 4. Mean numbers $(n=10) \pm$ mean of the standard errors (SEM) of three independent replicates for each experimental group of bacterial speck disease severity (DS) and reduction (DR) after different treatments containing tannins, either alone or in mixtures with half $(0.045 \% \mathrm{w} / \mathrm{v})$ of standard of copper hydroxide, at 7,14 and $21 \mathrm{~d}$ post inoculation (dpi) in tomato plants.

\begin{tabular}{|c|c|c|c|c|c|c|}
\hline \multirow{2}{*}{ Treatment } & \multicolumn{2}{|c|}{7 dpi } & \multicolumn{2}{|c|}{$14 \mathrm{dpi}$} & \multicolumn{2}{|c|}{$21 \mathrm{dpi}$} \\
\hline & DS (\%) & DR (\%) & DS (\%) & DR (\%) & DS (\%) & DR (\%) \\
\hline \multicolumn{7}{|l|}{ Seedlings } \\
\hline Ts (U1) & $16.67 \mathrm{~b}$ & $70.58 \mathrm{ab}$ & $27.50 \mathrm{~b}$ & $63.59 \mathrm{ab}$ & $40.00 \mathrm{~b}$ & $54.06 \mathrm{ab}$ \\
\hline Ts (U2) & $20.83 \mathrm{~b}$ & $61.34 \mathrm{ab}$ & $36.67 \mathrm{~b}$ & $51.19 \mathrm{ab}$ & $47.50 \mathrm{~b}$ & $45.27 \mathrm{ab}$ \\
\hline Ts (U3) & $26.67 \mathrm{ab}$ & $51.42 \mathrm{ab}$ & $39.17 \mathrm{~b}$ & $48.31 \mathrm{ab}$ & $49.17 \mathrm{~b}$ & $43.44 \mathrm{ab}$ \\
\hline Ts (U4) & $15.83 \mathrm{~b}$ & $70.92 \mathrm{ab}$ & $25.00 \mathrm{~b}$ & $66.94 \mathrm{a}$ & $32.50 \mathrm{~b}$ & $62.65 \mathrm{a}$ \\
\hline Ts $(\mathrm{U} 1)+1 / 2 \mathrm{Cu}(\mathrm{OH})_{2}$ & 24.17 b & $54.79 \mathrm{ab}$ & $31.67 \mathrm{~b}$ & $63.59 \mathrm{ab}$ & $35.83 \mathrm{~b}$ & $58.64 \mathrm{a}$ \\
\hline Ts $(\mathrm{U} 2)+1 / 2 \mathrm{Cu}(\mathrm{OH})_{2}$ & $25.83 \mathrm{ab}$ & $53.64 \mathrm{ab}$ & $40.83 \mathrm{~b}$ & $45.70 \mathrm{~b}$ & $54.17 \mathrm{~b}$ & $37.27 \mathrm{~b}$ \\
\hline $\mathrm{Ts}(\mathrm{U} 3)+1 / 2 \mathrm{Cu}(\mathrm{OH})_{2}$ & $12.50 \mathrm{~b}$ & $53.64 \mathrm{a}$ & $27.50 \mathrm{~b}$ & $63.25 \mathrm{ab}$ & $35.83 \mathrm{~b}$ & $58.69 \mathrm{a}$ \\
\hline $\mathrm{Ts}(\mathrm{U} 4)+1 / 2 \mathrm{Cu}(\mathrm{OH})_{2}$ & $28.33 \mathrm{ab}$ & $47.44 \mathrm{~b}$ & $40.83 \mathrm{~b}$ & $45.81 \mathrm{~b}$ & $50.00 \mathrm{~b}$ & $42.57 \mathrm{ab}$ \\
\hline Pst (negative control) & $53.33 \mathrm{a}$ & $\ldots$ & $75.00 \mathrm{a}$ & $\ldots$ & $86.67 \mathrm{a}$ & $\ldots$ \\
\hline $\mathrm{Cu}(\mathrm{OH})_{2}$ (standard) & $12.50 \mathrm{~b}$ & $77.94 \mathrm{a}$ & $20.83 \mathrm{~b}$ & $65.75 \mathrm{ab}$ & $35.83 \mathrm{~b}$ & $59.00 \mathrm{a}$ \\
\hline (S.E.M.) & 5.75 & 7.15 & 4.54 & 5.41 & 4.98 & 5.45 \\
\hline$P$ value & $P<0.01$ & $P<0.05$ & $P<0.01$ & $P<0.05$ & $P<0.01$ & $P<0.05$ \\
\hline \multicolumn{7}{|l|}{ Mature plants } \\
\hline Ts (U1) & $20.83 \mathrm{bc}$ & $62.85 \mathrm{ab}$ & $42.50 \mathrm{~b}$ & 39.51 & $58.33 \mathrm{~b}$ & 29.49 \\
\hline Ts (U2) & $36.67 \mathrm{~b}$ & $34.84 \mathrm{c}$ & 49.17 b & 29.63 & $60.00 \mathrm{~b}$ & 27.05 \\
\hline Ts (U3) & $24.17 \mathrm{bc}$ & $56.68 \mathrm{abc}$ & 39.17 b & 44.20 & $52.50 \mathrm{~b}$ & 36.43 \\
\hline Ts (U4) & $29.17 \mathrm{bc}$ & $47.89 \mathrm{bc}$ & $43.33 \mathrm{~b}$ & 38.02 & $51.67 \mathrm{~b}$ & 37.56 \\
\hline $\mathrm{Ts}(\mathrm{U} 1)+1 / 2 \mathrm{Cu}(\mathrm{OH})_{2}$ & $23.33 \mathrm{bc}$ & $58.50 \mathrm{abc}$ & $35.00 \mathrm{~b}$ & 50.00 & $50.83 \mathrm{~b}$ & 38.51 \\
\hline Ts $(\mathrm{U} 2)+1 / 2 \mathrm{Cu}(\mathrm{OH})_{2}$ & 34.17 b & $38.72 \mathrm{c}$ & $47.50 \mathrm{~b}$ & 32.10 & 59.17 b & 28.27 \\
\hline Ts $(\mathrm{U} 3)+1 / 2 \mathrm{Cu}(\mathrm{OH})_{2}$ & $23.33 \mathrm{bc}$ & $58.35 \mathrm{abc}$ & $41.67 \mathrm{~b}$ & 40.74 & $54.17 \mathrm{~b}$ & 34.61 \\
\hline Ts $(\mathrm{U} 4)+1 / 2 \mathrm{Cu}(\mathrm{OH})_{2}$ & $24.17 \mathrm{bc}$ & $56.90 \mathrm{abc}$ & $37.50 \mathrm{~b}$ & 46.54 & $55.83 \mathrm{~b}$ & 32.44 \\
\hline Pst (negative control) & $55.83 \mathrm{a}$ & $\ldots$ & $70.00 \mathrm{a}$ & $\ldots$ & $82.50 \mathrm{a}$ & $\ldots$ \\
\hline $\mathrm{Cu}(\mathrm{OH})_{2}$ (standard) & $13.33 \mathrm{c}$ & $76.21 \mathrm{a}$ & $35.00 \mathrm{~b}$ & 50.37 & $46.67 \mathrm{~b}$ & 43.72 \\
\hline (S.E.M.) & 3.60 & 5.38 & 3.94 & 4.98 & 4.66 & 4.85 \\
\hline$P$ value & $P<0.01$ & $P<0 P<0.05$ & $P<0.01$ & $P<0.05$ & $P<0.01$ & $P<0.05$ \\
\hline
\end{tabular}

Seedlings were treated 5, 10 and $15 \mathrm{~d}$ before inoculation, and mature plants were treated once at $24 \mathrm{~h}$ before inoculation. Treatments were with substances listed in Table 1 . DS was calculated by using the following formula: DS $(\%)=100 \times[($ number of plants in class $1 \times 1)+$ (number of plants in class $2 \times 2$ ) + (number of plants in class $3 \times 3)+($ number of plants in class $4 \times 4$ )] / (total number of plants in the treatment $\times 4)$. DR was calculated using the following formula: DR $(\%)=100 \times(\mathrm{DS}$ of control $-\mathrm{DS}$ of treatment $) /$ DS of control. The mean values in each column followed by different letters are significantly different $(P<0.01$ and $P<0.05)$ according to the Tukey HSD test.

which were significantly less than the negative control (mean $=55.8 \%)$. The tannins U1 (mean DS $=20.8 \%$ ), U3 (24.2\%), U4 (29.2\%), U1 + 1/2 Cu(OH) 2 (23.3\%), U3 $+1 / 2 \mathrm{Cu}(\mathrm{OH})_{2}(23.3 \%)$ and $\mathrm{U} 4+1 / 2 \mathrm{Cu}(\mathrm{OH})_{2}(24.2 \%)$, all reduced mean DS percentages in a manner similar to copper hydroxide (Mean DS $=13.3 \%$ ). U2 (mean DS = $36.7 \%)$ and $\mathrm{U} 2+1 / 2 \mathrm{Cu}(\mathrm{OH})_{2}(34.2 \%)$ did not protect the plants as much as copper hydroxide (13.3\%). At 14 and $21 \mathrm{dpi}$, all the tannin treatments (mean DS 35 to $49 \%$ at $14 \mathrm{dpi}$ and 50 to $60 \%$ at $21 \mathrm{dpi}$ ) gave similar DS to copper hydroxide (mean DS $=35.0 \%$ at $7 \mathrm{dpi}$ and 46.7 at 14 dpi). These treatments reduced DS compared to negative controls, which gave mean DS of $70 \%$ at 14 dpi and $86 \%$ at 21 dpi. Mean DR proportions at 7 dpi from the tannin formulations (56 to 62\%) were similar to those from copper hydroxide $($ mean $=76.2 \pm 5.4 \%$ ), with the exception of $\mathrm{U} 2$ (34.8\%), $\mathrm{U} 4$ (47.9\%) and $\mathrm{U} 2+1 / 2 \mathrm{Cu}(\mathrm{OH})_{2}(38.7 \%)$. No statistically significant differences in mean DR proportions were detected at 14 and $21 \mathrm{dpi}$.

Disease incidence

Table 5 shows the incidence of the disease in seedlings and mature plants.

On seedlings at $7 \mathrm{dpi}$, U1 (Mean DI = 53.3\%), U4 $(53.3 \%)$ and $\mathrm{U} 3+1 / 2 \mathrm{Cu}(\mathrm{OH})_{2}(33.3 \%)$, were able to 
Table 5. Mean numbers $(n=10) \pm$ mean of the standard errors $(S E M)$ of three independent replicates for each experimental group of bacterial speck disease incidence (DI) after different treatments containing tannins, either alone or in mixtures with half $(0.045 \%$ w/v) of standard of copper hydroxide, at 7, 14 and $21 \mathrm{~d}$ post inoculation (dpi) in tomato plants.

\begin{tabular}{|c|c|c|c|c|c|c|}
\hline \multirow{3}{*}{ Treatment } & \multicolumn{6}{|c|}{ Disease Incidence (\%) } \\
\hline & \multicolumn{2}{|c|}{7 dpi } & \multicolumn{2}{|c|}{$14 \mathrm{dpi}$} & \multicolumn{2}{|c|}{$21 \mathrm{dpi}$} \\
\hline & Seedlings & Mature plants & Seedlings & Mature plants & Seedlings & Mature plants \\
\hline Ts (U1) & $53.33 \mathrm{bc}$ & $80.00 \mathrm{ab}$ & $80.00 \mathrm{ab}$ & $96.67 \mathrm{ab}$ & $83.33 \mathrm{ab}$ & $96.67 \mathrm{ab}$ \\
\hline Ts (U2) & $73.33 \mathrm{abc}$ & $100 \mathrm{a}$ & $90.00 \mathrm{ab}$ & $100.00 \mathrm{a}$ & $90.00 \mathrm{ab}$ & $100.00 \mathrm{a}$ \\
\hline Ts (U3) & $63.33 \mathrm{abc}$ & $80.00 \mathrm{ab}$ & $76.67 \mathrm{ab}$ & $100.00 \mathrm{a}$ & $86.67 \mathrm{ab}$ & $100.00 \mathrm{a}$ \\
\hline Ts (U4) & $53.33 \mathrm{bc}$ & $96.67 \mathrm{a}$ & $66.67 \mathrm{~b}$ & $100.00 \mathrm{a}$ & $70.00 \mathrm{~b}$ & $100.00 \mathrm{a}$ \\
\hline $\mathrm{Ts}(\mathrm{U} 1)+1 / 2 \mathrm{Cu}(\mathrm{OH})_{2}$ & $73.33 \mathrm{abc}$ & $83.33 \mathrm{ab}$ & $80.00 \mathrm{ab}$ & $100.00 \mathrm{a}$ & $83.33 \mathrm{ab}$ & $100.00 \mathrm{a}$ \\
\hline $\mathrm{Ts}(\mathrm{U} 2)+1 / 2 \mathrm{Cu}(\mathrm{OH})_{2}$ & $60.00 \mathrm{abc}$ & $96.67 \mathrm{a}$ & $90.00 \mathrm{ab}$ & $100.00 \mathrm{a}$ & $90.00 \mathrm{ab}$ & $100.00 \mathrm{a}$ \\
\hline Ts $(\mathrm{U} 3)+1 / 2 \mathrm{Cu}(\mathrm{OH})_{2}$ & $33.33 \mathrm{~cd}$ & $80.00 \mathrm{ab}$ & $63.33 \mathrm{~b}$ & $96.67 \mathrm{ab}$ & $83.33 \mathrm{ab}$ & $100.00 \mathrm{a}$ \\
\hline $\mathrm{Ts}(\mathrm{U} 4)+1 / 2 \mathrm{Cu}(\mathrm{OH})_{2}$ & $76.67 \mathrm{ab}$ & $80.00 \mathrm{ab}$ & $86.67 \mathrm{ab}$ & $96.67 \mathrm{ab}$ & $90.00 \mathrm{ab}$ & $96.67 \mathrm{ab}$ \\
\hline Pst (negative control) & $100.00 \mathrm{a}$ & $100.00 \mathrm{a}$ & $100.00 \mathrm{a}$ & $100.00 \mathrm{a}$ & $100.00 \mathrm{a}$ & $100.00 \mathrm{a}$ \\
\hline $\mathrm{Cu}(\mathrm{OH})_{2}$ (standard) & $36.66 \mathrm{bc}$ & $53.33 \mathrm{~b}$ & $63.33 \mathrm{~b}$ & $80.00 \mathrm{~b}$ & $70.00 \mathrm{~b}$ & $86.67 \mathrm{~b}$ \\
\hline (S.E.M.) & $8.88 \mathrm{E}-02$ & $6.41 \mathrm{E}-02$ & $5.68 \mathrm{E}-02$ & $3.65 \mathrm{E}-02$ & $5.87 \mathrm{E}-02$ & $2.58 \mathrm{E}-02$ \\
\hline$P$ value & $P<0.01$ & $P<0.01$ & $P<0.01$ & $P<0.05$ & $P<0.05$ & $P<0.05$ \\
\hline
\end{tabular}

Seedlings were treated 5, 10 and $15 \mathrm{~d}$ before inoculation, and mature plants were treated once $24 \mathrm{~h}$ before inoculation. Treatments were with substances listed in Table 1 . dpi = days post inoculation; DI was calculated as the percentage of plants with at least one symptom $/ 10$ (total number of plants per experimental group). Different letters within the same column indicate significant differences $(P<0.01$ and $P<$ $0.05)$ according to the Tukey HSD test.

reduce mean disease incidence compared to the negative control (Pst). At 14 dpi, U4 (66.7\%) and $\mathrm{U} 3+1 / 2 \mathrm{Cu}(\mathrm{OH})_{2}$ (63.3\%) reduced the disease incidence compared to negative control (Pst), while all the tannin treatments did not show significant reduction compared to the negative control and the standard (mean DI =63.3\%). At $21 \mathrm{dpi}$, only $\mathrm{U} 4$ used alone (Mean DI $=70.0 \%$ ) reduced disease incidence compared to the negative control (Pst), while all the tannin treatments ( 83 to 90\%) did not give significant reductions compared to the negative control and the standard (Mean DI $=70.0 \%$ ).

On mature plants, at 7,14 and $21 \mathrm{dpi}$, none of the tannin treatments reduce disease incidence compared to the negative control (Pst).

\section{Biostimulant effects of tannins on seedling tomato plants}

Leaf development

Table 6 shows the effects of the different treatments on seedling tomato plants, expressed as average leaf surface area $\left(\mathrm{cm}^{2}\right)$. After treatment with tannins, the sampled tomato leaves showed no symptoms of burning or bleaching. Nevertheless, the average leaf areas recorded for plants receiving the tannin formulations were less compared to the water controls. At $1 \mathrm{dpi}$, no signifi- cant differences were recorded, but at 7 and 14 dpi all the tannin and copper hydroxide treatments gave significantly less mean leaf areas than the TPE (the positive control) and water treatments. At $21 \mathrm{dpi}$, U1 applied alone (mean leaf area $=15.8 \mathrm{~cm}^{2}$ ) increased the leaf area surface compared to copper hydroxide $\left(11.8 \mathrm{~cm}^{2}\right)$ and the negative control $\left(11.3 \mathrm{~cm}^{2}\right)$, but not compared to water control $\left(13.5 \mathrm{~cm}^{2}\right)$. At 7, 14 and $21 \mathrm{dpi}$, TPE gave a biostimulant effect on aerial biomass development of the plants.

Nitrogen Balance Indices (NBI)

Table 7 presents the mean NBI values after treatments of plants, as general indices of their state of health. All the tannin formulations (mean NBI $=19.5$ to 24.3) did not increase the NBI values compared to water treatment (22.0), but the mean NBI index of plants treated with tannin formulations increased only compared to the negative control (8.4).

\section{Shoots development}

Table 7 shows the results for biostimulant effects of the different treatments on plant biomass expressed as mean shoot dry weights (g) at $21 \mathrm{dpi}$. The dry weight of 
Table 6. Mean leaf surface areas $(n=10) \pm$ mean of the standard errors (SEM) of three independent replicates for each experimental group after different treatments containing tannins, either alone or in mixtures with half $(0.045 \% \mathrm{w} / \mathrm{v})$ of standard of copper hydroxide, at $1,7,14$ and $21 \mathrm{~d}$ post inoculation (dpi) in seedling tomato plants.

\begin{tabular}{|c|c|c|c|c|}
\hline \multirow{2}{*}{ Treatment } & \multicolumn{4}{|c|}{ Average leaf surface area $\left(\mathrm{cm}^{2}\right)$} \\
\hline & $1 \mathrm{dpi}$ & $7 \mathrm{dpi}$ & $14 \mathrm{dpi}$ & $21 \mathrm{dpi}$ \\
\hline Ts (U1) & 11.51 & $14.97 \mathrm{c}$ & $13.09 \mathrm{c}$ & $15.84 \mathrm{~b}$ \\
\hline Ts (U2) & 14.14 & $12.98 \mathrm{c}$ & $12.62 \mathrm{c}$ & $14.50 \mathrm{bc}$ \\
\hline Ts (U3) & 10.99 & $13.89 \mathrm{c}$ & $11.66 \mathrm{c}$ & $14.37 \mathrm{bc}$ \\
\hline Ts (U4) & 9.07 & $11.83 \mathrm{c}$ & $12.73 \mathrm{c}$ & $11.05 \mathrm{c}$ \\
\hline Ts $(\mathrm{U} 1)+1 / 2 \mathrm{Cu}(\mathrm{OH})_{2}$ & 10.44 & $13.15 \mathrm{c}$ & $12.85 \mathrm{c}$ & $12.88 \mathrm{bc}$ \\
\hline Ts $(\mathrm{U} 2)+1 / 2 \mathrm{Cu}(\mathrm{OH})_{2}$ & 8.68 & $11.47 \mathrm{c}$ & $13.99 \mathrm{c}$ & $14.76 \mathrm{bc}$ \\
\hline Ts $(\mathrm{U} 3)+1 / 2 \mathrm{Cu}(\mathrm{OH})_{2}$ & 8.12 & $10.40 \mathrm{c}$ & $11.57 \mathrm{c}$ & $13.25 \mathrm{bc}$ \\
\hline Ts $(\mathrm{U} 4)+1 / 2 \mathrm{Cu}(\mathrm{OH})_{2}$ & 9.62 & $13.15 \mathrm{c}$ & $12.10 \mathrm{c}$ & $11.60 \mathrm{c}$ \\
\hline Pst (negative control) & 8.93 & $12.41 \mathrm{c}$ & $12.11 \mathrm{c}$ & $11.27 \mathrm{c}$ \\
\hline $\mathrm{Cu}(\mathrm{OH})_{2}$ (standard) & 9.19 & $12.60 \mathrm{c}$ & $12.23 \mathrm{c}$ & $11.78 \mathrm{c}$ \\
\hline TPE (positive control) & 14.33 & $26.31 \mathrm{a}$ & $25.15 \mathrm{a}$ & $18.72 \mathrm{a}$ \\
\hline $\mathrm{H}_{2} \mathrm{O}$ (blank control) & 10.44 & $21.01 \mathrm{~b}$ & $20.01 \mathrm{~b}$ & $13.51 \mathrm{bc}$ \\
\hline (S.E.M.) & 1.347 & 1.212 & 1.148 & 0.811 \\
\hline$P$ value & $P<0.01$ & $P<0.01$ & $P<0.01$ & $P<0.01$ \\
\hline
\end{tabular}

Table 7. Mean values of Nitrogen Balance Indices $(n=40)$ and dry weight of shoots $(n=10) \pm$ mean of the standard errors (SEM) of three independent replicates for each experimental group after different treatments containing tannins, either alone or in mixtures with half $(0.045 \% \mathrm{w} / \mathrm{v})$ of standard of copper hydroxide, at $21 \mathrm{~d}$ post inoculation (dpi) in seedling tomato plants.

\begin{tabular}{lcc}
\hline Treatment & $\begin{array}{c}\text { NBI } \\
(\text { DUALEX) }\end{array}$ & $\begin{array}{c}\text { Dry weight of shoots } \\
(\mathrm{g})\end{array}$ \\
\hline Ts $(\mathrm{U} 1)$ & $19.54 \mathrm{c}$ & $1.130 \mathrm{~b}$ \\
Ts $(\mathrm{U} 2)$ & $19.60 \mathrm{c}$ & $0.913 \mathrm{bc}$ \\
Ts $(\mathrm{U} 3)$ & $20.31 \mathrm{c}$ & $0.837 \mathrm{bc}$ \\
Ts $(\mathrm{U} 4)$ & $24.28 \mathrm{~b}$ & $0.952 \mathrm{bc}$ \\
$\mathrm{Ts}(\mathrm{U} 1)+1 / 2 \mathrm{Cu}(\mathrm{OH})_{2}$ & $21.74 \mathrm{bc}$ & $1.020 \mathrm{bc}$ \\
$\mathrm{Ts}(\mathrm{U} 2)+1 / 2 \mathrm{Cu}(\mathrm{OH})_{2}$ & $20.68 \mathrm{c}$ & $0.913 \mathrm{bc}$ \\
Ts $(\mathrm{U} 3)+1 / 2 \mathrm{Cu}(\mathrm{OH})_{2}$ & $21.79 \mathrm{bc}$ & $0.978 \mathrm{bc}$ \\
Ts $(\mathrm{U} 4)+1 / 2 \mathrm{Cu}(\mathrm{OH})_{2}$ & $21.65 \mathrm{bc}$ & $0.912 \mathrm{bc}$ \\
Pst $($ negative control) & $8.39 \mathrm{~d}$ & $0.516 \mathrm{c}$ \\
$\mathrm{Cu}(\mathrm{OH})_{2}($ standard $)$ & $20.51 \mathrm{c}$ & $0.597 \mathrm{c}$ \\
TPE (positive control) & $26.25 \mathrm{a}$ & $1.560 \mathrm{a}$ \\
$\mathrm{H}_{2} \mathrm{O}($ blank control $)$ & $21.98 \mathrm{bc}$ & $0.907 \mathrm{bc}$ \\
$($ S.E.M.) & 0.703 & 0.078 \\
$P$ value & $P<0.01$ & $P<0.01$ \\
\hline
\end{tabular}

Seedlings were treated three times 5,10 and $15 \mathrm{~d}$ before inoculation. Treatments were with substances listed in Table 1. Different letters within each column indicate significant differences $(P<0.01)$ according to the Tukey HSD test. shoots of $\mathrm{U} 1$ treated plants (mean $=1.13 \mathrm{~g}$ ) was similar to the water control $(0.91 \mathrm{~g})$, but greater than for copper hydroxide treated plants $(0.60 \mathrm{~g})$ and the negative control plants $(0.52 \mathrm{~g})$, while the rest tannin treatments (means $=0.84$ to $1.02 \mathrm{~g}$ ) did not show significant differences compared to water, copper and negative control plants. The TPE treatment increased the shoot dry weight. Statistically significant differences in mean root dry weights were not detected (data not shown).

\section{DISCUSSION}

This study has demonstrated that condensed and hydrolysable tannins exhibited antimicrobial activity against Pst, as shown by their in vitro effectiveness to completely inhibit Pst growth $24 \mathrm{~h}$ after inoculation. The chestnut, tara, and quebracho tannins prevented in vitro growth of Pst. Several studies have evaluated the antibacterial activity of hydrolysable and condensed tannins towards different bacteria. Gallotannins (hydrolysable) obtained from tara pod extracts and their hydrolysis product have been assessed for activity against gram-positive and gram-negative bacteria (including Staphylococcus aureus and Pseudomonas fluorescens) (Aguilar-Galvez et al., 2014)antioxidant activity, antimicrobial activity (AA. Previous research has shown that crude tannin extracts more effectively inhibited pathogenic bacteria than pure molecules (Akhtar et al., 2015). For this reason, the present study concentrated on four tannin formulations instead of their components. Few evaluations of crude tannin extracts from chestnut, quebracho and tara plant matrices against phytopathogenic bacteria have been carried out, but many studies have assessed anti-bacterial activity of these tannins. Elizondo et al. (2010) tested quebracho and chestnut tannins, applied alone or mixed, for activity against toxinotypes of Clostridium perfringens. In the present study, the highest MIC values for the quebracho tannins was $0.12 \%$, while the lowest one $(0.015 \%)$ was observed for chestnut tannins. In our study we also obtained a similar trend, observing MIC values of $1 \%$ for U2 (quebracho tannins) and $0,5 \%$ for U1 (chestnut tannins), while the MIC values of the chestnut and quebracho tannins were $0.5 \%$ for both the U3 (90:10) and U4 (50:50). It is likely that the greater MIC values resulted from the use of the tannin extracts towards a gram-negative bacterium. This bacterium could be resistant to tannins because it possesses a lipopolysaccharide cell membrane which provides strength and prevents the cell penetration of bioactive compounds (Puupponen-Pimiä et al., 2005). Elizondo et al. (2010) demonstrated that chestnut tannins 
extract was more efficient than quebracho. Our study results are similar, since $\mathrm{U} 1$ and $\mathrm{U} 3$, chestnut-based tannins, were more effective in controlling Pst than U2. Elizondo et al. (2010) observed that the antibacterial effects of quebracho tannins increased by up to 20 times after adding $25 \%$ of chestnut tannins, and by up to 85 times with $75 \%$ of chestnut tannins. They concluded that the antibacterial activity of the mixed products was approx. 50 times greater than quebracho tannins applied alone. Results from the our study were similar, since U4, a mixture of $50 \%$ quebracho tannins and $50 \%$ of chestnut tannins, showed similar antibacterial activity to U1. During the in vitro assay by incorporating the tannins into the $\mathrm{KB}$ medium, we observed that no Pst growth was recorded at 24 and $48 \mathrm{~h}$ after incubation, except for U2 mixed with the $50 \%$ dose of copper hydroxide, where Pst CFUs were present after $48 \mathrm{~h}$ incubation. Our hypothesis is that this may be related to copper precipitation, because of the chelation activity of tannins. Some studies have reported that chelation ability is strongly related to the molecular weight of condensed tannins (Yoneda and Nakatsubo, 1998; Karamać, 2009). Since U2 is composed of condensed tannins, it is likely that their structures chelated copper hydroxide, thus inactivating copper hydroxide and tannins, allowing Pst growth.

For the antibacterial in vivo trials, tannin treatments reduced Pst epiphytic survival and disease severity (DS) compared to negative control treatments (Pst), while the disease incidence (DI) was not influenced by the tannin applications. Karamanoli et al. (2011) reducing its bioavailability to plant-associated bacteria. In response to limited iron levels, most bacteria produce siderophores to acquire needed iron quantities. The amount of phenolic compounds detected in methanolic washings of leaves of different plant species varied greatly, being nearly sevenfold higher in Viburnum tinus than in Phaseolus vulgaris. In species with high levels of total phenolics (e.g. Pelargonium hortorum suggested that the antibacterial activity of tannins was due to their ability to chelate iron, reducing its bioavailability to phytopathogenic bacteria. Although the biological role of tannins is mainly attributed to their ability to bind proteins (Smith et al., 2005), Karamanoli et al. (2011) concluded that iron sequestration by tannins was a dominant factor inhibiting bacterial growth on host plant leaves. This iron chelating ability has been also supported by Engels et al. (2009). We therefore conclude that the antibacterial activity of tannins towards Pst could be an indirect effect from their capacity to prevent the pathogen from taking up some essential nutrients, such as metal ions.

Other studies have evaluated tannins extract for effects on plant pathogenic bacteria. For example, $\mathrm{Vu}$ et al. (2013) evaluated the effects of diluted tannins from Sedum takesimense corresponding to concentrations of 1 and $0.5 \%$, on $R$. solanacearum. At 14 dpi they observed dose-dependent disease reductions, of $78 \%$ from $1 \%$ and $54 \%$ from $0.5 \%$. Vu et al. (2017) tested tannins extract from $S$. baccatum towards $R$. solanacearum at concentrations of $0.1 \%$ and $0.2 \%$, demonstrating disease reduction of $63 \%$ from $0.1 \%$ and $83 \%$ from $0.2 \%$, at $14 \mathrm{dpi}$. In the present study, disease reductions of 45 to $63 \%$ in seedlings and 30 to $50 \%$ in mature plants were also recorded at $14 \mathrm{dpi}$. Despite the fact that in this study, and in those cited above, tannins have been shown to have antimicrobial activity, it is highly reductive, to make comparisons between active tannin concentrations. Firstly, tannin concentrations in crude extracts change depending on genetic and environmental factors applying to different tannin-producing plant species. Secondly, these concentrations can also vary depending on the methods of extraction and fractioning used to obtain the pure molecules (Nader et al., 2010).

Although tannins have been studied as biostimulators of plant roots (Bargiacchi et al., 2013), in the present study biostimulant effects on tomato plants were not detected, as the data obtained were similar to those from watertreated plants. Nevertheless, it is important to determine if the tannin treatments were not toxic to tomato plants.

\section{CONCLUSIONS}

The results obtained in this research have highlighted the possibility of using natural compounds (tannins) for reducing Pst populations on tomato plants, as a "green" strategy that is similarly efficacious as cupric salts for the control of tomato bacterial speck. Further research is required, including evaluation of possible induction of defensive genes and defence metabolites (e.g. salicylic acid) in tomato plants, and the production of reactive oxygen species (ROS).

This research has highlighted innovative crop protection strategies aimed assess the use of natural products for management of bacterial plant diseases. This will assist reduction of the use of cupric salts in agricultural disease and pest control programmes, minimising potential impacts of these materials on human and environmental health.

\section{LITERATURE CITED}

Aguilar-Galvez A., Noratto G., Chambi F., Debaste F., Campos D., 2014. Potential of tara (Caesalpinia spi- 
nosa) gallotannins and hydrolysates as natural antibacterial compounds. Food Chemistry 156: 301-304.

Akhtar S., Ismail T., Fraternale D., Sestili P., 2015. Pomegranate peel and peel extracts: chemistry and food features. Food Chemistry 174: 417-425.

Arbenz A., Avérous L., 2016. Tannins: a resource to elaborate aromatic and biobased polymers. Biodegradable and Biobased Polymers for Environmental and Biomedical Applications: 97-148.

Aroso I.M., Araújo A.R., Pires R.A., Reis R.L., 2017. Cork: current technological developments and future perspectives for this natural, renewable, and sustainable material. ACS Sustainable Chemistry and Engineering 5: 11130-11146.

Bacelo H.A.M., Santos S.C.R., Botelho C.M.S., 2016. Tannin-based biosorbents for environmental applications - A review. Chemical Engineering Journal 303: 575-587.

Baka Z., Rashad Y., 2016. Alternative control of early blight disease of tomato using the plant extracts of Acacia nilotica, Achillea fragrantissima and Calotropis procera. Phytopathologia Mediterranea 55: 121-129.

Balestra G.M., Varvaro L., 1998. Seasonal fluctuations in kiwifruit phylloshere. Journal of Plant Pathology 80: 151-156.

Barbehenn R., Constabel C., 2011. Tannins in plant-herbivore interactions. Phytochemistry 72: 1551-1565.

Bargiacchi E., Costa G., Della Croce C., Foschi L., Pampana S., ... Rizzi G., 2004. Method for obtaining organic acidifying solutions and fertilizers using organic extracts from aqueous wood leaching processes Eur. Pat. EP1464635, 24-03-2010, priority: IT2003MI00640 2003-03-31. : 1-12.

Bargiacchi E., Miele S., Romani A., Campo M., 2013. Biostimulant activity of hydrolyzable tannins from sweet chestnut (Castanea sativa Mill.). Acta Horticulturae 1009: 111-116.

Bargiacchi E., Campo M., Romani A., Milli G., Miele S., 2017. Hydrolysable tannins from sweet chestnut (Castanea sativa Mill.) to improve tobacco and food/ feed quality. Note 1: fraction characterization, and tobacco biostimulant effect for gall-nematode resistance. AIMS Agriculture and Food 2: 324-338.

Biancalani C., Cerboneschi M., Tadini-Buoninsegni F., Campo M., Scardigli A., ... Tegli S., 2016. Global analysis of type three secretion system and quorum sensing inhibition of Pseudomonas savastanoi by polyphenols extracts from vegetable residues. PLoS ONE 11: 1-21.

Caruso G., De-Pascale S., Cozzolino E., Cuciniello A., Cenvinzo V., ... Rouphael Y., 2019. Yield and nutritional quality of vesuvian piennolo tomato PDO as affected by farming system and biostimulant application. Agronomy 9: 505-517.

Colla G., Rouphael Y., Di-Mattia E., El-Nakhel C., Cardarelli M., 2015. Co-inoculation of Glomus intraradices and Trichoderma atroviride acts as a biostimulant to promote growth, yield and nutrient uptake of vegetable crops. Journal of the Science of Food and Agriculture 95: 1706-1715.

De Hoyos-Martínez P.L., Merle J., Labidi J., Charrier-El Bouhtoury F., 2019. Tannins extraction: a key point for their valorization and cleaner production. Journal of Cleaner Production 206: 1138-1155

Devash Y., Okon Y., Henis Y., 1980. Survival of Pseudomonas tomato in soil and seeds. Journal of Phytopathology 99: 175-185.

Elizondo A.M., Mercado E.C., Rabinovitz B.C., Fernandez-Miyakawa M.E., 2010. Effect of tannins on the in vitro growth of Clostridium perfringens. Veterinary Microbiology 145: 308-314.

Engels C., Knödler M., Zhao Y.Y., Carle R., Gänzle M.G., Schieber A., 2009. Antimicrobial activity of gallotannins isolated from mango (Mangifera indica L.) kernels. Journal of Agricultural and Food Chemistry 57: 7712-7718.

Francesconi S., Steiner B., Buerstmayr H., Lemmens M., Sulyok M., Balestra G.M., 2020. Chitosan hydrochloride decreases Fusarium graminearum growth and virulence and boosts growth, development and systemic acquired resistance in two durum wheat genotypes. Molecules 25: 4752. doi:10.3390/molecules 25204752 .

Giovanardi D., Ferrari M., Stefani E., 2015. Seed trasmission of Acidovorax citrulli: implementazion of detection in watermelon seeds and development of disinfection methods. Proceedings of the 7th Congress on Plant Protection. Plant Protection Society of Serbia, 71-75.

Giovando S., Pizzi A., Pasch H., Pretorius N., 2013. Structure and oligomers distribution of commercial tara (Caesalpina spinosa) hydrolysable tannin. Pro Ligno 9: 22-31.

Gruda N., 2005. Impact of environmental factors on product quality of greenhouse vegetables for fresh consumption. Critical Reviews in Plant Sciences 24: 227-247.

Haslam E., Lilley T.H., Cai Y., Martin R., Magnolato D., 1988. Traditional herbal medicines. Planta Medica 55: $1-8$.

He L., Sequeira L., Kelman A., 1983. Characteristics of strains of Pseudomonas solanacearum from China. Plant Disease 67: 1357-1361.

Hernes P.J., Hedges J.I., 2004. Tannin signatures of barks, needles, leaves, cones, and wood at the molecular 
level. Geochimica et Cosmochimica Acta 68: 12931307.

Hümmer W., Schreier P., 2008. Analysis of proanthocyanidins. Molecular Nutrition and Food Research 52: 1381-1398.

Kalleli F., Abid G., Salem I. Ben, Boughalleb-M'Hamdi N., M'Hamdi M., 2020. Essential oil from fennel seeds (Foeniculum vulgare) reduces fusarium wilt of tomato (Solanum lycopersicon). Phytopathologia Mediterranea 59: 63-76.

Karamać M., 2009. Chelation of $\mathrm{Cu}(\mathrm{II}), \mathrm{Zn}(\mathrm{II})$, and $\mathrm{Fe}(\mathrm{II})$ by tannin constituents of selected edible nuts. International Journal of Molecular Sciences 10: 5485-5497.

Karamanoli K., Bouligaraki P., Constantinidou H.I.A., Lindow S.E., 2011. Polyphenolic compounds on leaves limit iron availability and affect growth of epiphytic bacteria. Annals of Applied Biology 159: 99-108.

Katagiri F., Thilmony R., He S.Y., 2002. The Arabidopsis thaliana-Pseudomonas syringae Interaction. The Arabidopsis Book 1: e0039.

King E.O., Ward M.K., Raney D.E., 1954. Two simple media for the demonstration of pyocyanin and fluorescin. The Journal of Laboratory and Clinical Medicine 44: 301-307.

La Torre A., Iovino V., Caradonia F., 2018. Copper in plant protection: current situation and prospects. Phytopathologia Mediterranea 57: 201-236.

Lochab B., 2014. Naturally occurring phenolic sources: monomers and polymers. RSC Advances 4: 2171221753. doi:10.103.

Marrone P.G., 2019. Pesticidal natural products - status and future potential. Pest Management Science 75: 2325-2340.

McCarter S.M., Jones J.B., Gitaitis R.D., Smitley D.R., 1983. Survival of Pseudomonas syringae pv. tomato in association with tomato seed, soil, host tissue, and epiphytic weed hosts in Georgia. Phytopathology 73: 1393-1398.

Mekam P.N., Martini S., Nguefack J., Tagliazucchi D., Mangoumou G.N., Stefani E., 2019. Activity of extracts from three tropical plants towards fungi pathogenic to tomato (Solanum lycopersicum). Phytopathologia Mediterranea 58: 573-586.

Molino S., Fernández-Miyakawa M., Giovando S., RufiánHenares J.Á., 2018. Study of antioxidant capacity and metabolization of quebracho and chestnut tannins through in vitro gastrointestinal digestion-fermentation. Journal of Functional Foods 49: 188-195.

Nader T., Coppede J., Amaral L., Facchin A., Pereira A., Ferreira L., 2010. Avaliação in vitro da eficácia de extratos de plantas medicinais do cerrado frente
Staphylococcus aureus isolado de diferentes fontes de propriedades leiteiras. Arquivod do Instituto Biològico 77: 429-433.

Pietrarelli L., Balestra G.M., Varvaro L., 2006. Effects of simulated rain on Pseudomonas syringae pv. tomato populations on tomato plants. Journal of Plant Pathology 88: 245-251.

Pizzi A., Pasch H., Rode K., Giovando S., 2009. Polymer structure of commercial hydrolyzable tannins by matrix-assisted laser desorption/ionization-time-offlight mass spectrometry. Journal of Applied Polymer Science 113: 3847-3859.

Puupponen-Pimiä R., Nohynek L., Hartmann-Schmidlin S., Kähkönen M., Heinonen M., ... Oksman-Caldentey K.-M., 2005. Berry phenolics selectively inhibit the growth of intestinal pathogens. Journal of Applied Microbiology 98: 991-1000.

Quattrucci A., Balestra G.M., 2009. Antibacterial activity of natural extracts in Pseudomonas syringae pv. tomato control. Acta Horticulturae 808: 339-341.

Quattrucci A., Ovidi E., Tiezzi A., Vinciguerra V., Balestra G.M., 2013. Biological control of tomato bacterial speck using Punica granatum fruit peel extract. Crop Protection 46: 18-22.

Quideau S., Deffieux D., Douat-Casassus C., Pouységu L., 2011. Plant polyphenols: chemical properties, biological activities, and synthesis. Angewandte Chemie - International Edition 50: 586-621.

Radebe N., Rode K., Pizzi A., Giovando S., Pasch H., 2013. MALDI-TOF-CID for the microstructure elucidation of polymeric hydrolysable tannins. Journal of Applied Polymer Science 128: 97-107.

Renčo M., Sasanelli N., Papajová I., Maistrello L., 2012. Nematicidal effect of chestnut tannin solutions on the potato cyst nematode Globodera rostochiensis (Woll.) Barhens. Helminthologia 49: 108-114.

Schneider R.W., Grogan R.G., 1976. Bacterial speck of tomato: sources of inoculum and establishment of a resident population. Phytopathology 67: 388-394.

Smith A.H., Zoetendal E., Mackie R.I., 2005. Bacterial mechanisms to overcome inhibitory effects of dietary tannins. Microbial Ecology 50: 197-205.

Steel R.G.D., Dickey D.A., Torrie J.H., 1997. Principles and procedures of statistics: a biometrical approach. New York : McGraw-Hill, New York, 666 pp.

Varvaro L., Fanigliulo R., Babelegoto N.M., 1993. Transmission electron microscopy of susceptible and resistant tomato leaves following infection with Pseudomonas syringae pv. tomato. Journal of Phytopathology 138: 265-273.

Venter P.B., Senekal N.D., Amra-Jordaan M., Bonnet S.L., Westhuizen J.H. Van der., 2012. Analysis of commer- 
cial proanthocyanidins. Part 2: An electrospray mass spectrometry investigation into the chemical composition of sulfited quebracho (Schinopsis lorentzii and Schinopsis balansae) heartwood extract. Phytochemistry 78: 156-169.

Vu T.T., Kim J.C., Choi Y.H., Choi G.J., Jang K.S., ... Lee S.W., 2013. Effect of gallotannins derived from Sedum takesimense on tomato bacterial wilt. Plant Disease 97: 1593-1598.

Vu T.T., Kim H., Tran V.K., Vu H.D., Hoang T.X., ... Kim J.C., 2017. Antibacterial activity of tannins isolated from Sapium baccatum extract and use for control of tomato bacterial wilt. PLoS ONE 12: 1-12.

Vurro M., Miguel-Rojas C., Pérez-de-Luque A., 2019. Safe nanotechnologies for increasing the effectiveness of environmentally friendly natural agrochemicals. Pest Management Science 75: 2403-2412.

Yoneda S., Nakatsubo F., 1998. Effects of the hydroxylation patterns and degrees of polymerization of condensed tannins on their metal-chelating capacity. Journal of Wood Chemistry and Technology 18: 193205. 